\title{
Implementation of the Flipped Classroom Model in the Scientific Ethics Course
}

\author{
Mehmet URFA ${ }^{1}$ \\ Gürhan DURAK ${ }^{2}$ \\ 'Army NCO Vocational College, National Defence University, Turkey \\ -Assistant Professor Gürhan Durak, Department of Computer Education and Instructional Technologies, \\ Ballkesir University, Turkey
}

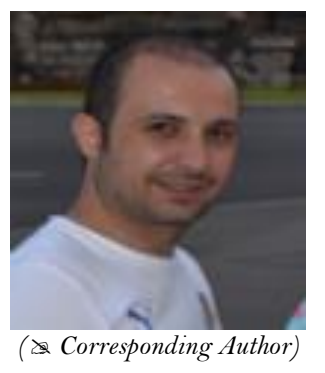

\section{Abstract}

In the present study, the purpose was to determine students' views about the application of Flipped Classroom Model (FL), in which, different from the traditional method, homework is replaced by in-class activities and which has frequently been mentioned recently. The study was carried out with 24 students from the department of Computer Education and Instructional Technologies within the scope of the Scientific Ethics Course for in a period of 11 weeks in 2016. In the research process, stud groups were formed to let the students carry out the in-class applications collaboratively. In the study, the research data were collected via structured observation form, observation, structured interview form and focus group interview. The study was carried out on qualitative basis with quantitative support. In the quantitative dimension of the study, descriptive statistics was applied, and in the qualitative dimension, thematic analysis method was used. In the study, for the collection and analysis of the data, Rogers's Diffusion of Innovations Theory was used as the theoretical framework. In this respect, with the data collected from the participants, the advantages and disadvantages of the FL model were determined. The findings obtained in the study revealed that the participants had positive views about their collaborative learning thanks to the FL model within the scope of the Scientific Ethics Course; that the model increased their motivations; that the model should be used more commonly; and that they wanted to prefer to teach with this model in their future professional lives.

Keywords: Flipped classroom model, Scientific ethics course.

Citation | Mehmet URFA; Gürhan DURAK (2017) Implementation of the Flipped Classroom Model in the Scientific Ethics Course. Journal of Education and e-Learning Research, 4(3): 108-117.

History:

Received: 29 September 2017

Revised: 13 October 2017

Accepted: 16 October 2017

Published: 19 October 2017

Licensed: This work is licensed under a Creative Commons

Attribution 3.0 License (c)

Publisher:Asian Online Journal Publishing Group
Contribution/Acknowledgement: Both authors contributed to the conception and design of the study.

Funding: This study received no specific financial support

Competing Interests: The authors declare that they have no conflict of interests.

Transparency: The authors confirm that the manuscript is an honest, accurate, and transparent account of the study was reported; that no vital features of the study have been omitted; and that any discrepancies from the study as planned have been explained.

Ethical: This study follows all ethical practices during writing.

\section{Contents}

1. Introduction

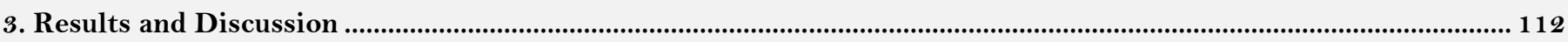

4. Conclusion ...unumu.u.u. 115

References. 


\section{Introduction}

Scientific and technological developments, which have led to important changes in a number of areas of life, have also changed people's way of accessing information and communicating each other (Turan, 2015). With the development of mobile communication technologies, the current age is called information age (Kurudayığlu and Tüzel, 2010) use of information and communication tools in education has gradually become widespread. With these changes, the need for active learning environments based on constructivism for learners has increased.

Today, the necessity for involvement in global learning environments has increased in line with the increase in opportunities for learning. Higher-level thinking skills and information literacy skills have come into prominence, and use of traditional methods for teaching and assessing students may sometimes fail to meet students' expectations today (Roehl et al., 2013; Vaughan, 2014; O’Flaherty and Pilips, 2015). This situation has increased the interest in and expectations from technology use in education, and educators have started to carry out studies on new teaching methods (Hung, 2015). Since 1980s, thanks to the important advances in information and communication technologies, the computer-aided learning method has allowed students to become independent of the traditional face-to-face education, and these developments have removed various limitations related to time, place and age and facilitated the transfer of course content to out-of-class environment (Baker, 2000; Demirkan et al., 2016). In this respect, in order to increase in-class activities and to give education based more on in-class applications, use of innovative learning environments with the traditional method has gradually become widespread.

Not only the use of digital learning technologies in face-to-face learning environments but also the combined use of the advantageous aspects of face-to-face and distance education methods depending on the needs has resulted in the blended learning method (Ünsal, 2012; Geçer, 2013). Blended learning environments allow not only distance learning in digital environments but also face-to-face learning in traditional class environments (Singh, 2003). Staker and Horn (2012) examined the blended learning model under four headings. The researchers mentioned the "Flipped Learning (FL)" model (a model frequently reported in related literature) under the heading of the flipped model, which is a blended learning model. The FL model is defined by Baker (2000) as a teaching approach, in which, different from the traditional course structure, homework and teaching are replaced mutually and in which students are provided with the opportunity to work in more collaboration. In other words, the FL model is regarded as a blended learning model in which the content shared in the traditional class environment is transferred to an online platform and in which the activities planned as homework are carried out in the traditional class environment under the guidance of the teacher (Demiralay and Karataş, 2014).

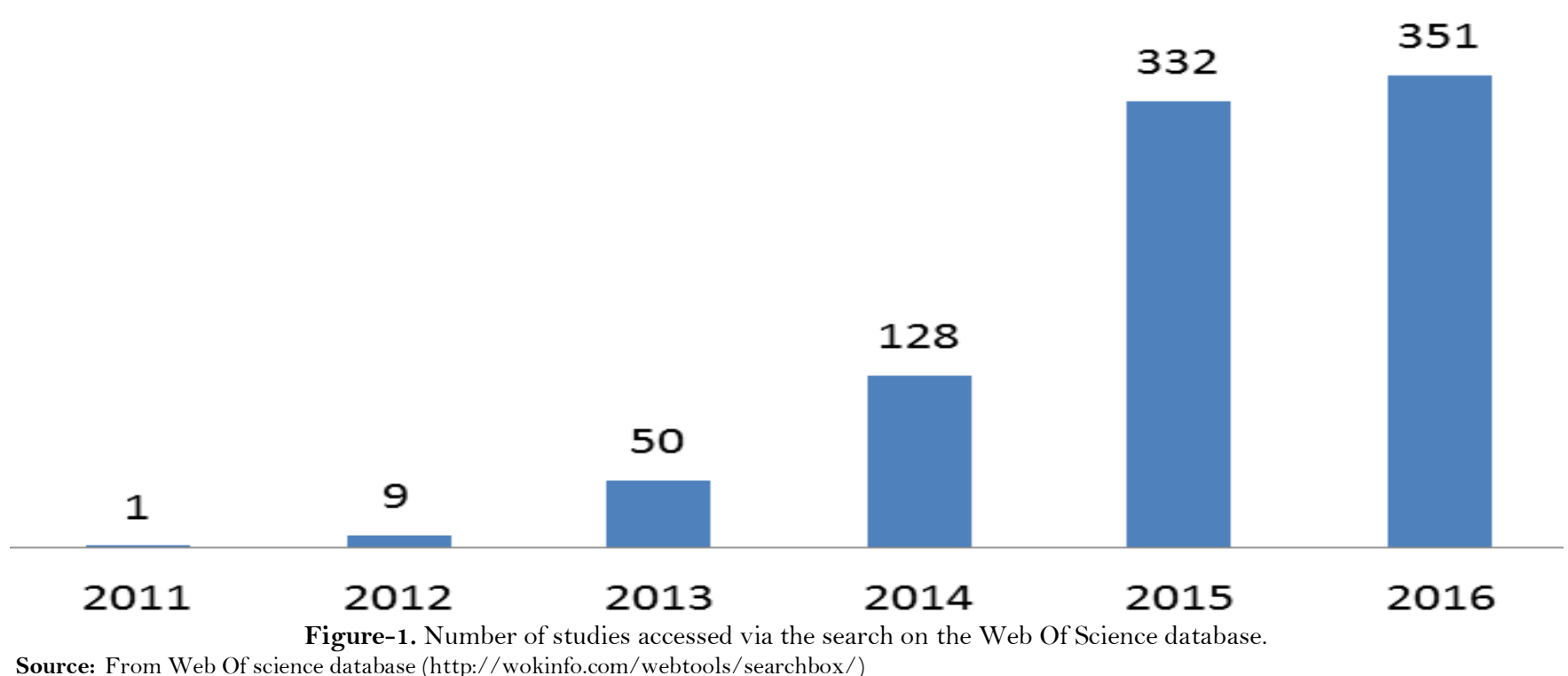

As can be seen in Figure 1, a total of 871 studies were listed as a result of the search on the Web of Science database. According to Figure 1, there was an increase in the number of studies by year.

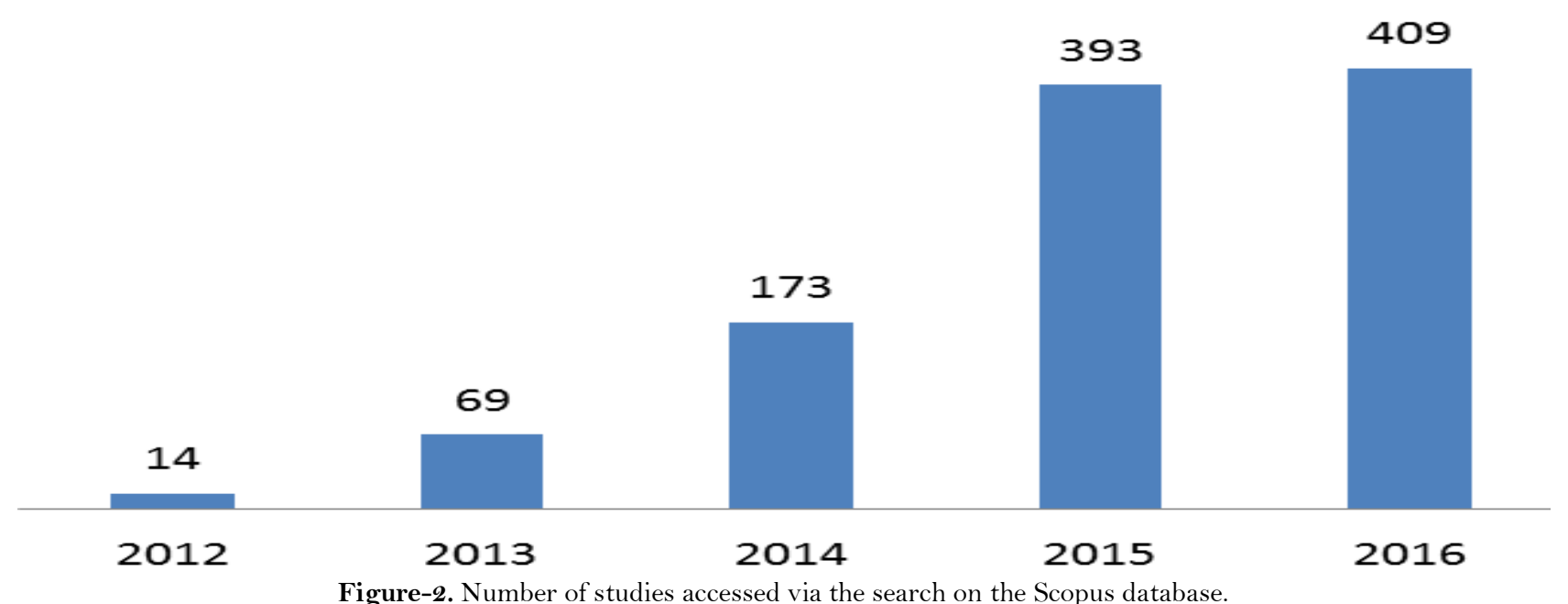

Source: From Scopus database (www.scopus.com) 
Using the same keywords for the search on the Scopus database, a total of 1201 studies were listed as can be seen in Figure 2. Similarly, the increase in the number of studies by year is important. When the results presented in Figure 1 and Figure 2 are considered together, it could be stated that the FL model is a new concept in related literature and that its importance is gradually increasing.

In the present study, the Scientific Ethics Course was structured with the FL model. In related literature, there are a number of studies carried out on the importance of non-ethical behaviors in scientific studies and publications within the scope of the subject of scientific ethics (Uçak and Birinci, 2008; Erdem, 2012; Karadeniz, 2015; Özcan and Balc1, 2016). One of the prominent finding obtained in these studies regarding ethics education is lack of training on doing research necessary for training scientists (Özcan and Balcl, 2016). Therefore, it is important for students to know what non-ethical behaviors are, to follow the current situation and developments and to be knowledgeable about the sanctions to be imposed in relation to non-ethical behaviors, about the negative effects of mistakes in scientific studies on the society and about several other related issues.

When studies in related literature are examined, it is seen that the FL model was applied in various fields such as computer education, foreign language teaching, social studies education and medical education as well as in other basic areas. However, it is seen that there is no research on the application of the FL model regarding the teaching of Scientific Ethics Course. For this reason, the present study could be said to be the first study carried out using the FL model based on the collaborative learning theories and on the diffusion of innovations theory.

The purpose of the study was to determine learners' views about the FL model applied in the Scientific Ethics Course. In line with this overall purpose, the following research questions were directed in relation to the subproblems:

1. What are difficulties experienced in the application of the FL model?

2. What are learners' views about the course executed with the FL model?

3. What are learners' views about the dissemination of the FL model?

\subsection{Theoretical Framework}

In the study, the in-class activities were carried out collaboratively. According to Açıkgöz (1992) collaborative learning method can be defined as students' working in small study groups for a common puprose in class environment in a way to contribute to each other's learning. The theory which constitutes the basis of the study and which is used for the analysis of the data as well is the Diffusions of Innovations Theory (DIT). The theory provides basis for research on new technologies. DIT was suggested by Rogers (2003) and it consists of four main elements: innovation, communication channels, time, and a social system. In his theory, Rogers defines "innovation" as an idea, an application or an object considered to be new by an individual or organization. An innovation does not have to be a concept or a design that is definitely unknown. If an organization or individuals have not used it yet, it can be regarded as an innovation (Berger, 2005).

\section{Method}

\subsection{Research Model}

The present study, which aimed to determine learners' views about the FL model applied for the Scientific Ethics Course, was carried out using the mixed design, in which the quantitative and qualitative methods were used together. According to Creswell (2014) the basic purpose of using mixed methods is to complement poor or deficient aspects of a paradigm with another paradigm. In this way, it could be stated that a more powerful structure can be established in terms of methodology.

\subsection{Data Collection Tools}

In the study, the qualitative dimension of the study included the structured observation form data. As for the qualitative dimension of the study, it included observations, individual interviews and focus group interview. The researcher took notes about how the faculty member applied the FL model in the course throughout the application process and about the students' attitudes, views and behaviors regarding various subjects. In the study, individual interviews were held with all the students to collect data in relation to their thoughts about the FL model, their satisfaction with the model, the difficulties they experienced in the process, their attitudes regarding the use of the FL model in other courses, and their thoughts about whether they would use the FL model in their future professional lives. For the interviews, it was assumed that the students were sufficiently knowledgeable about the traditional model. In this way, it was thought that they would be able to discriminate between their learning with the traditional model and their learning with the FL model.

\subsection{Participants}

In the study, the research sample included senior students attending the department of Computer Education and Instructional Technologies at a state university in $2016(n=24)$. Within the scope of the study, eight groups with three students in each were formed with the integration of the FL model into the collaborative learning environment. The students were asked to form their groups on their own and allowed to select their friends for their groups. In this way, it was thought that they would form groups with their friends who they knew well and who would contribute positively to their own learning. Table 1 presents the codes for the groups and students.

Table-1. Collaborative study groups: Group and student codes

\begin{tabular}{l|l|l|l|l|l|l|l}
\hline G1 & G2 & G3 & G4 & G5 & G6 & G7 & G8 \\
\hline S1-S3 & S4-S6 & S7-S9 & S10-S12 & S13-S15 & S16-S18 & S19-S21 & S22-S24 \\
\hline
\end{tabular}

G: Study group code, S: learner code 


\subsection{Data Analysis}

In the study, for the analysis of the quantitative data, structured observation form was used to determine the differences between the groups and to determine the groups' levels of active participation in in-class applications. For the analysis of the data, percentages (\%), frequencies (f) and mean scores were used. For the other data collection tools used in the study such as observation, individual interview and focus group interview, the qualitative data analysis method was applied. The data collected via the interviews were categorized into themes, and while conducting the analyses regarding these themes, direct quotations were frequently used to reflect the learners' views.

\subsection{Validity and Reliability}

In order to ensure the validity and reliability of the observation data, the researcher watched the video-records of the in-class applications at the end of each class hour again and did the necessary arrangements by examining the consistency of the video-recorded data and the structured observation form data. In this way, the purpose was to prevent data loss. In addition, the video-records regarding the qualitative data collected via the individual interviews and focus group interviews were transformed into texts in computer environment. The questions prepared for the interviews were presented to two faculty members expert in the field besides the faculty member giving the course, and in line the expert views, the necessary arrangements were done. Also, the focus group interviews were video-recorded and then transformed into texts to prevent data loss. After consistency was ensured, the data were categorized in accordance with the diffusion of innovations theory and analyzed.

\subsection{Application Process}

Throughout the research process of 11 weeks, the students participated in in-class and out-of-class activities. Within the scope of the study, the students took part in in-class discussions and in question-answer and homework activities. The lessons were given in the computer laboratory. Although the Scientific Ethics Course is a theoretical course, the students had the opportunity to carry out the in-class activities using the computer.

In the study, before the application of the FL model, in the first class hour, the students were informed about the model, and grouping was done. The groups and the teaching environment for the course were formed in the platform of Edmodo, a leading Social Learning Network (SLN) in the world, and the students were asked to join the Scientific Ethics Course group in Edmodo. In the study, after all the 24 students joined Edmodo, the study groups were formed.

The sharings related to the lesson subjects in the curriculum were done via Edmodo three days before the related class hour. The content of the course included the videos ready on the Internet, press clippings, articles and the videos and presentations prepared by the faculty member. In literature, there are a number of studies reporting the positive influence of students' learning via videos (Orhan, 1999; Ocak, 2004; Pekdağ, 2010; Çiğdem, 2015). In this respect, special attention was paid to weekly video sharing. The in-class applications included the assignments and discussions. Word documents including 5 to 8 questions related to the subject were prepared. These documents were shared with the students, and the students were asked to write down their responses below the questions in groups. At the end of the allocated time, the students were requested to send their homework via Edmodo. After the homework documents prepared in groups were uploaded to Edmodo, the faculty member started the discussion part. In this part, the faculty member directed the same questions to the students again, and the students who wanted to say word were asked to report their views in relation to the questions. In line with the students' responses, the faculty member also directed further questions related to the same question and tried to contribute the students' critical thinking. Meanwhile, the researcher, in the role of a passive observe, took notes regarding active participations of the students and of the groups.

In the research process, the materials previously prepared/determined were uploaded for the course group every lesson week. In addition, special attention was paid to the fact that the course materials would be appropriate to the mobile platforms, and the materials were generally uploaded to Edmodo on the first day of the week. Table 2 presents the types of weekly sharings.

Table-2. Course materials and contents for the Scientific Ethics Course on weekly basis

\begin{tabular}{l|l}
\hline Lesson Week & Content \\
\hline W1 & Orientation training (Forming the study groups) \\
\hline W2 & Power Point Presentation \\
\hline W3 & Video \\
\hline W4 & Clip, YouTube videos \\
\hline W5 & Video \\
\hline W6 & Video \\
\hline W7 & Video, Clip \\
\hline W8 & Article (clip), article (clip), Video \\
\hline W9 & Video, article (clip) \\
\hline W10 & Article \\
\hline W11 & Video, article \\
\hline * The videos were prepared by the researcher and by the faculty member
\end{tabular}

\subsection{Researcher's Role}

In the whole process from the orientation training to the focus group interview held at the end of the academic term, the researcher was in the role of a passive observer during the lessons. The researcher the faculty member giving the course did various research on the lesson subject via the Internet and in the university library, examined the studies on scientific ethics, and prepared the course contents accordingly. The course contents were uploaded for the groups via Edmodo by the faculty member. For the in-class applications, the questions related to the subjects were directed to the students during the in-class applications by the faculty member. 


\section{Results and Discussion}

In this part of the study, the results obtained have been presented and interpreted by comparing them with those of other studies in related literature.

\subsection{Students' Levels of Participation in the Lessons}

The learners and groups were given codes, and the researcher took notes about their active participations in inclass applications. In this respect, the purpose was to determine the participation levels of the learners and of the learner groups in in-class activities, to keep records of their progress in the process and to determine the sample for the focus group interview by noting down the students' levels of participation.

Table 3 presents data regarding the collaborative learning groups' levels of participation in class.

Table-3. Groups' levels of participation in in-class applications

\begin{tabular}{|c|c|c|c|c|c|c|c|c|c|c|c|}
\hline $\mathbf{G} / \mathbf{W}$ & We & W3 & $\mathrm{H} 4$ & W5 & W6 & W7 & W8 & W9 & W10 & W11 & Mean \\
\hline G1 & 5 & 4 & 7 & 5 & 5 & 4 & 4 & 3 & 5 & 10 & 5,2 \\
\hline $\mathrm{G}_{2}$ & 4 & 2 & 2 & 4 & 3 & 1 & 3 & 2 & 1 & 1 & 2,3 \\
\hline G3 & 4 & 1 & 3 & 1 & 2 & 1 & 2 & 3 & 5 & 2 & 2,4 \\
\hline G4 & 8 & 3 & 3 & 2 & 2 & 1 & 2 & 4 & 3 & 2 & 3 \\
\hline G5 & 3 & 1 & 3 & 2 & 2 & 2 & 2 & 1 & 1 & 2 & 1,9 \\
\hline G6 & 6 & 1 & 2 & 1 & 2 & $\mathrm{O}$ & 2 & 1 & 2 & 2 & 1,9 \\
\hline G7 & 4 & 2 & 4 & 4 & 1 & 1 & 4 & 2 & 2 & 2 & 2,6 \\
\hline G8 & 2 & 3 & 1 & 2 & 1 & $\mathrm{O}$ & 1 & 3 & 1 & 1 & 1,5 \\
\hline
\end{tabular}

W: Related lesson week; Mean: Mean active participation in class

When Table 3 is examined, it is seen that the two study groups did not participate actively in the whole application process only once. In addition, all the groups participated actively at least once in every lesson. As a result of the collaborative group works, involvement of the students in active learning environments increased. Similarly, Yavuz (2016) stated that collaborative learning environment increases interaction between students and creates a positive learning framework.

\subsection{FL Difficulties Experienced in the Application of the Model}

Different from the studies in related literature regarding the FL model, in the present study, active participations of the learners and of the learner groups in in-class applications were noted down. It was seen that the learners were more active in in-class activities when compared to the traditional model. Also, video-recording of the process contributed to this situation.

In order to increase applicability of the FL model, it is necessary for the learner group to have the ability to use certain technologies. The observation notes revealed that most of the students who had technological efficacy due to their department followed the course contents via mobile platforms.

In FL model, learners are expected to carry out out-of-class activities, to watch the related videos, read the lecture notes and to be ready for the lessons by studying via electronic sources. Out-of-class sharings can be done via the Internet with the help of a number of tools such as social media tools, YouTube, social learning networks and so on. However, Edmodo is a social learning network developed only for educational purposes. A number of applications which allow forum discussion, homework assignment, sharing subjects, giving exams and monitoring students' activities are available on Edmodo both for teachers and students. As in many studies in related literature (Durak et al., 2014; Sucu et al., 2015; Dere and Yalçınalp, 2016; Durak, 2017) such tools of Edmodo as video uploading, homework assignment, giving and collecting homework, giving external links, providing a discussion environment and exam tools were used effectively in the present study as well.

Videos in online learning environments have been among the most popular course materials for learners. Learners prefer to learn by listening rather than by reading. In relation to this, Ekren and Akkul (2013) pointed out that videos used in education technologies allow students to teaching a subject in association with the outcomes of that subject and help reach more information in a shorter period of time and that use of videos addressing more than one sense like auditory and visual senses allows teaching in an interactive way to prevent students from getting bored, which in turn has positive effects on their motivation.

It could be stated that with the application of the FL model in collaborative learning environment, a positive framework of learning leading to a more student interaction in class is formed when compared to the traditional learning model. Similarly, Strayer (2012); Yavuz (2016) and Larson and Yamamoto (2013) reported that although they did not use the collaborative learning method in their studies, the students trained using the FL model interacted with each other more collaboratively when compared to the traditional method. In the study, it was also revealed that the study groups participated actively in in-class discussions almost every lesson week. This finding supports those of other studies which revealed that students participate actively in class thanks to the in-class activities in the FL model (Enfield, 2013; Hurley, 2014; Hung, 2015).

In the present study, although the learners' motivations were not measured empirically, the learners' motivations could be said to be positively influenced by the facility that allowed the learners to follow the lessons easily and by the use of active learning activities in class. In literature, there are several studies reporting that similar blended learning environments increase learners' motivations (Chao et al., 2015; Sirakaya, 2015; Turan, 2015). In this respect, it could be stated that the FL model provided active learning environments and allowed the learners to learn on their own pace of learning by accessing the learning sources at any time they want, which was an important factor increasing their motivations. 


\subsection{Learners' Views about the FL Model}

In the study, the purpose of the individual interviews and the focus group interviews was to determine the students' views about the FL model. The data collected via the interviews were coded, and the following themes were obtained: FL model readiness, general views about FL model, effectiveness of FL and dissemination of FL model. These themes were interpreted within the framework of the "Diffusion of Innovations Theory".

Table-4. FL model readiness

\begin{tabular}{l|l}
\hline Themes & Frequency (f) \\
\hline Awareness of FL model & \\
\hline I don't have any knowledge/experience regarding FL model & 24 \\
\hline Expectations from FL Model & \\
\hline Enthusiastic & 11 \\
\hline Entertaining & 9 \\
\hline Different/Interesting & 6 \\
\hline Worrying & 5 \\
\hline I have no expectation & 3 \\
\hline
\end{tabular}

When Table 4 is examined, it is seen that the participants had no preliminary knowledge about the FL model. Therefore, the FL model could be said to be an innovation for the learners.

In the study, it was found that the participants had positive/negative expectations after being told that the course would be taught using the FL model. It was also seen that three of the students did not have any expectations regarding the FL model. The expectations from the model were mostly found to be enthusiastic, entertaining, different/interesting and worrying. As the learners met an innovation for the first time in their education lives, the fact that they got excited as well as worried about the innovation and regarded the innovation as an entertaining and different learning environment was an expected result. Similarly, Turan (2015) reported that learners have negative expectations regarding the FL model as they are accustomed to taking lessons with the traditional method. As mentioned by Mason et al. (2013) it could be stated that students may show resistance to a new learning model and that they are also likely to change their attitudes in the application process though and to be satisfied with taking lessons using the model.

Table-5. General views about the FL model

\begin{tabular}{l|l}
\hline Themes & Frequency (f) \\
\hline General Views about the FL Model & \\
\hline It allows active participation in lessons & 10 \\
\hline It provides an entertaining learning environment & 5 \\
\hline It makes it easier for me to express myself & 5 \\
\hline More effective learning occurs thanks to the collaborative work environment & 4 \\
\hline It contributes to permanent learning & 3 \\
\hline It helps getting ready for the lessons in advance & 3 \\
\hline
\end{tabular}

When Table 5 is examined, it is seen that the most common views of the students about the FL model was the finding of "It allows active participation in lessons". In relation to this, S2 said "It was a class environment which allowed everyone to share ideas with each other, to state their own ideas directly, and to say whether they agree or disagree with others' ideas. Thanks to this, we understood the subjects better. In the past, we used to learn something via the materials shared and used to reinforce in class what we had learned." This was followed by the responses of "It provides an entertaining learning environment", "It makes it easier for me to express myself", and "more effective learning occurs thanks to the collaborative work". Similar to these results, studies in related literature reported that the FL model allowed learners to participate more actively in lessons, provided an entertaining learning environment, contributed to the permanency of learners' knowledge, helped students prepare for classes in advance and created a collaborative positive framework of learning (Sırakaya, 2015; Aydın, 2016; Yavuz, 2016).

Table-6. Effectiveness of FL model

\begin{tabular}{l|l}
\hline Themes & Frequency (f) \\
\hline Advantages when compared to the traditional method & \\
\hline Learning the concepts more permanently & 5 \\
\hline Allowing more active participation in in-class activities & 8 \\
\hline Providing a student-centered learning environment & 3 \\
\hline Carrying out individual out-of-class learning activities & 3 \\
\hline helping prepare for classes in advance & 2 \\
\hline Disadvantages when compared to the traditional method & \\
\hline Difficult to apply in basic courses (Physics, chemistry, biology) & 4 \\
\hline Requiring more readiness when compared to the traditional model & 1 \\
\hline Problems caused by technical malfunctions & 3 \\
\hline Levels of understanding the lessons & \\
\hline Positive effects in terms of motivation & 19 \\
\hline Collaborative learning environment & 6 \\
\hline Benefits of homework & 2 \\
\hline Direct access to course materials (sources) & 18 \\
\hline Influence on teaching scientific ethics & 24 \\
\hline
\end{tabular}

The participants were asked to compare the FL model with traditional methods, and the advantages and disadvantages of the FL model were grouped under two headings. Most of the participants reported that the 
advantages of the FL model included in-class applications and active participation in class and that the model allowed learning the subjects more permanently when compared to the traditional methods. One of the students, S24, who mentioned the advantage of active learning environment, said "I would like the lessons to be taught with the flipped classroom model. Lessons taught using the traditional method are boring. I think when students become active and learn on their own by searching, then they learn more permanently." Another, S4, mentioned permanency of knowledge thanks to the FL model, saying "I prefer the flipped classroom model because when the traditional method is used for teaching, you leave the information in class, and absolutely, at home, no student revise or study on again what they have learned in class. On the other hand, in the flipped classroom model, you already prepare for lessons before going to school, and the question-andanswer technique applied in class makes permanent what you have learned in class." Another point made by the participants was that they could carry out out-of-class activities individually and got ready for the lessons in advance. In relation to this, one of the students, S3, said "In this course, we learned new concepts with this model. We prepared for the lessons before the class hour by watching videos and reading articles. In this way, we learned the subjects easily. We also had the opportunity to watch the videos again."

According to the interviews held based on the assumption that the students were experienced in traditional learning, almost all the students reported that they wanted to learn the lessons with the FL model. It could be stated that class time is allocated to teaching in traditional models might have been influenced on the students' preference of the FL model. In this respect, studies comparing the traditional method with the FL model (Yavuz, 2016) demonstrated that students taking education with the FL model have higher performance when compared to those taking education with the traditional method.

In the study, the students' responses to the questions directed to determine their views about the disadvantages of the FL model revealed that they considered these disadvantages to include technical malfunctions, difficulty in applying the model to other subjects, the need for more computer knowledge and skills and inapplicability of the model to all education levels. In relation to this, one of the study, S17, said "For example, it is difficult to use the model in the course of Mathematics. You mostly do mathematical calculations in the course of math. I think it would be more beneficial if the teacher teaches the subject in class". In addition, S2, another student, mentioned the need for a certain level of readiness saying "It is hard to apply the flipped method without having a certain level of readiness. Also, one should have basic computer knowledge, responsibility for studying alone, and efficacy in reading comprehension. Some of the participants reported that it was possible to meet various technical problems with the FL model. Regarding this, one of the students, S16, said "It was a bit boring to read the pdf documents. Also, there were long and boring videos at the beginning. I think the course contents should be uploaded earlier."

In the study, some of the participants stated that the FL model was an applicable model and that it would not be possible to apply it to all courses, though. They generally thought that the method can be used in social courses in the form of discussion and question-and-answer techniques. Similarly, Demiralay (2014) points out that one of the limited aspects of the FL model is that the model can be used best in non-mathematical courses. The related situation in the present study could be said to due to the fact that the students met the FL model for the first time and used the model with the collaborative learning method. On the other hand, it is seen in studies in related literature that the FL model was applied mostly to mathematical courses (Strayer, 2012; Bishop and Vergeler, 2013; Davies et al., 2013; Talley and Scherer, 2013; Wilson, 2013; Baepler et al., 2014).

The participants were asked to respond to the question of "Did the contents have any influence on your motivation?" to reveal whether the FL model was influential on their learning scientific ethics. In relation to this, a heading related to their levels of understanding the lessons was formed. When the participants' levels of the participation in classes were examined, it was seen that they demonstrated a high level of participation. Most of the participants stated that the contents increased their motivations. Regarding this, one of the students, S1, said "The contents were important in terms of our motivation. When a lesson starts, it should draw students' attention first, and the videos were really interesting. As interrogative videos were used in the lessons, they really arose our curiosity. In this way, they encouraged us to do search and to participate more actively in classes." Another student, S5, mentioned the influence of the collaborative learning environment with the FL model, saying "The method was effective in terms of our learning together with our friends. We produce common ideas with our group friends and responded to the questions. When one of had no idea, another friend of ours had one. In this way, we filled the gap." Another student, S17, explained the influence of in-class applications / homework, saying "The homework we did with our group friends in class was really influential on our learning." In relation to access to the course materials out of class time, S22 said "The course materials were always available, and we didn't waste time taking notes during the lessons. I mean we didn't have to deal with taking notes about the lesson subjects." All the students reported that the FL model was influential on their learning scientific ethics. Regarding this, one of the students, S23, said "I got enough knowledge about this subject within the scope of this course. Thus, I think all faculties giving undergraduate education must include this course in their curriculum as a compulsory course."

In the study, the students' views about the course materials revealed that the video contents motivated the learners more since reading the texts was found boring. Similarly, in a study carried out by Deperlioglu and Köse (2010) the researchers reported that use of multimedia technologies in presenting the course content to students provided them with a collaborative and constructivist learning environment and that such technologies as presentations, videos, audios and visuals used for an effective lesson had positive influence on students' achievements. These findings are also consistent with those obtained in other studies in related literature (Kenna, 2014; Stifle, 2014). Regarding the videos related to the lesson subjects, the students stated that the videos should not be too long. Similarly, Torkelson (2012) points out that videos should be prepared in a way to summarize the lesson subject in five to seven minutes.

In line with the students' views, it was concluded that scientific ethics education should be given at earlier class grades to raise students' awareness of scientific ethics. Similarly, in related literature, there are several studies focusing on the importance of ethics education (Uçak and Birinci, 2008; Erdem, 2012; Karadeniz, 2015; Özcan and Balc1, 2016). In addition, at the end of the course, the students reported that their views about scientific ethics changed; that they learned the correct form of what they had already known wrongly; and that they would use their knowledge about ethics in their future academic lives. 
Table-7. Dissemination of the FL model

\begin{tabular}{l|l}
\hline Themes & Frequency (f) \\
\hline Application to other courses & \\
\hline To non-mathematical courses & 13 \\
\hline To other courses in the department & 5 \\
\hline To all the courses & 8 \\
\hline General views about the dissemination of the FL model & \\
\hline Such applications will have an important place in future education system & 14 \\
\hline It is more appropriate to higher education & 6 \\
\hline Our colleagues should know about this method & 4 \\
\hline
\end{tabular}

In the study, the participants were asked which other courses in their department or in other departments besides the Scientific Ethics Course are suitable for the application of the FL model. The students' responses generally revealed that it would be better to apply the model ton on-mathematical courses. In relation to this, one of the students, S17, said "I don't think the model is appropriate to all courses. It is a method appropriate to nonmathematical courses which are based on production of ideas". In addition, the participants the method should be tested in other courses in the department as well. Regarding this, another student, S11, said "The application and dissemination of the model in other courses in the department similar to our course will bear good results." Also, some of the participants reported that the FL model was a method applicable to all courses. In relation of this, one of the students, S20, said "I think it can be used in all areas of education. The only problem is that classrooms are crowded."

\section{Conclusion}

The present study, which aimed to determine learners' views about the FL model applied in the Scientific Ethics Course, focused on their views about the difficulties experienced in the application of the model, about the course executed with the FL model and about the dissemination of the FL model.

According to the results of the observations and interviews, the students mostly reported views about interactions between students and about their active participation in class. The students stated that they learned about new ideas thanks to their group friends. Most of the students reported that they would use the method in their courses and prefer it to traditional methods. It was also found that the FL model applied in teaching the Scientific Ethics Course contributed positively to the students' learning. In addition, the students pointed out that the course materials raised their awareness, drew their interest and contributed to their learning. Moreover, most of the students stated that they would use the method in their future professional lives when they got the necessary computer use knowledge. In the light of these data, it could be stated that collaborative application of the FL model allows students' active participation in class; that the video contents draw their attention and contribute to their learning; that they prefer to teach lessons using this method in their professional lives; and that teaching scientific ethics is an important subject.

The findings obtained in the study can be interpreted in terms of the "Diffusion of Innovations Theory (DIT)": The fact that the learners' lack of knowledge or experience regarding the FL model before this application caused them to perceive the FL model to be an innovation. Considering the fact that the learners had confidence in the FL model applied in the Scientific Ethics Course and found it beneficial, it could be stated that they adopted this innovation. In addition, the learners generally reported positive views about the dissemination of such applications and pointed out that the method could be useful especially in undergraduate education. When all these implications are taken into account as a whole, these thoughts of the learners could be explained as diffusion of the related innovation.

Consequently, as mentioned by Merrill (2002) use of instructional technologies in education will make the related education effective and productive. Depending on the research data collected in the present study, it could be stated that the application of the FL model will contribute to the establishment of effective teaching environments.

\subsection{Suggestions}

\subsubsection{Suggestions for Practitioners}

1. If the Scientific Ethics Course is given at the beginning of undergraduate education rather than at postgraduate education level, students will raise their awareness of this subject, pay attention to the subject of ethics in their homework, and get prepared for their academic lives earlier. In this respect, it is thought that the Scientific Ethics Course could be included in the curricula at undergraduate education level.

2. The students mostly wanted the course contents to include short, comprehensible and up-to-date videos appropriate to their levels. In addition, the students also stated that watching videos rather than reading the shared texts drew their interest more. In this respect, preparing short videos regarding the contents for the FL model could increase learners' motivation in classes/subjects.

3. Course materials should be shared in a way to allocate enough time before the in-class application. In the present study, the learners mostly reported such a problem. Therefore, in this study, it was concluded that course materials should be shared at least three days before in-class applications.

\subsubsection{Suggestions for Researchers}

1. In line with the students' views, The FL model, more favorable when compared to the traditional model, can be applied in all fields of education. The method can be applied in a number of fields such as history, geography, mathematics and sports education besides medical education, computer education, foreign language teaching and laboratory education. 
2. Using different learning management systems as the course platform (Moodle, Blackboard and), empirical studies measuring the variables in question (academic achievement, motivation and attitude) can be conducted.

3. The FL model could be applied to learner groups from different education levels (elementary school, high school, postgraduate education).

4. In future studies, besides the collaborative application of the FL model, use of different theories and models could lead to different results.

5. Experimental studies could be conducted using more quantitative data when the number of students is enough for such an application within the scope of this course.

\section{References}

Açıkgöz, K.Ü., 1992. Cooperative learning: Theory research application. Malatya: Uğurel Press.

Aydın, B., 2016. Academic achievement, homework / task stress level and impact on learning transfer of the reverse classroom model. Graduate Thesis, Süleyman Demirel University, Institute of Educational Sciences. Isparta: Department of Computer and Instructional Technology Education.

Baepler, P., J.D. Walker and M. Driessen, 2014. It's not about seat time: Blending, flipping, and efficiency in active learning classrooms. Computers \& Education, 78: 227-236. View at Google Scholar | View at Publisher

Baker, J.W., 2000. The classroom flip: Using web course management tools to become the guide by the side. Selected Papers from the 11 th International Conference on College Teaching and Learning, 9-17. Jacksonville: Florida Community College: In J. A. Chambers.

Berger, J.I., 2005. Perceived consequences of adopting the internet into adult literacy and basic education classrooms. Adult Basic Education, 15(2): 103-121. View at Google Scholar

Bishop, J.L. and M.A. Vergeler, 2013. The flipped classroom: A survey of the research. 120th ASEE Conference \& Exposition. American Society for Engineering Educatio, Atlanta.

Chao, C., Y. Chen and K. Chuang, 2015. Exploring students' learning attitude and achievement in flipped learning supported computer aided design curriculum: A study in high school engineering education. Computer Applications in Engineering Education, 23(4): 514526. View at Google Scholar | View at Publisher

Çiğdem, H., 2015. How does self-regulation affect computer-programming achievement in a blended context? Contemporary Educational Technology, 6(1): 19-37. View at Google Scholar

Creswell, J.W., 2014. Research design: Qualitative, quantitative, and mixed methods approaches. 4th Edn., CA:Sage: Thousand Oaks.

Davies, R.S., D.L. Dean and N. Ball, 2013. Flipping the classroom and instructional technology integration in a college-level information systems spreadsheet course. Education Technology Research Development, 61(4): 563-580. View at Google Scholar|View at Publisher

Demiralay, R., 2014. Examination of the adoption process of the homework model at home in the framework of innovation propagation theory. Doctorate Thesis, Gazi University, Institute of Educational Sciences, Department of Educational Sciences, Ankara.

Demiralay, R. and S. Karataş, 2014. Homework lesson School homework model. Journal of Education and Training Researches, 3(3): 333340. View at Google Scholar

Demirkan, Ö., E. Bayra and E. Baysan, 2016. The effect of distance education students' follow-up on the success of their courses. Turkey Social Studies Journal, $20(1): 47-75$.

Deperlioglu, Ö. and U. Köse, 2010. The influence of web 2.0 technologies on education and a sample learning experience. 10. Academic Informatics Conference. Mugla University Faculty of Education, Mugla.

Dere, E. and S. Yalçınalp, 2016. Opinions of primary school pupils regarding Edmodo as an educational online social learning environment. Primary Education Online, 15(3): 804-819. View at Google Scholar

Durak, G., 2017. Using social learning networks (SLNs) in higher education: Edmodo through the lenses of academics. International Review of Research in Open and Distributed Learning, 18(1): 84-109. View at Google Scholar | View at Publisher

Durak, G., S. Çankaya and E. Yünkül, 2014. Use of educational social network sites in education: Edmodo example. Dumlupınar University Journal of Social Sciences, 41: 309-316. View at Google Scholar

Ekren, N. and N. Akkul, 2013. Assessment Steps of Computer and Internet Assisted Distance Education Programs (UZEM Orneti). Abstracts, 21.

Enfield, J., 2013. Looking at the impact of the flipped classroom model of instruction on undergraduate multimedia students at CSUN. TechTrends, 57(6): 14-27. View at Google Scholar | View at Publisher

Erdem, A.R., 2012. Education of ethics in cultivation of science people. Journal of Higher Education and Science, 2(1): 25-32. View at Google Scholar

Geçer, A., 2013. Instructor-student communication in blended learning environments. Educational Sciences in Theory and Practice, 13(1): 349-367. View at Google Scholar

Hung, H., 2015. Flipping the classroom for english language learners to foster active learning. Computer Assisted Language Learning, 28(1): 81-96. View at Google Scholar |View at Publisher

Hurley, K.S., 2014. A case study of learner and instructor perceptions of flipped course design and interactive learning environment. International Journal Social Media and Interactive Learning Environments, 2(4): 361-377. View at Google Scholar |View at Publisher

Karadeniz, A., 2015. Lecture design in open and distance learning: A case of science lesson lesson. Journal of Open Education Practices and Research, 1(3): 91-107. View at Google Scholar

Kenna, D.C., 2014. A study of the effect the flipped classroom model on student selfefficacy. Master's Thesis, North Dakota State University, Fargo, North Dakota.

Kurudayığlu, M. and S. Tüzel, 2010. Century literacy types, changing text sense and Turkish education. Turkish Science Research, 28(28): 283-298. View at Google Scholar

Larson, S. and J. Yamamoto, 2013. Flipping the college spreadsheet skills classroom: Initial empirical results. Journal of Emerging Trends in Computing and Information Sciences, 4(10): 75 1-758. View at Google Scholar |View at Publisher

Mason, G.S., T.R. Shuman and K.E. Cook, 2013. Comparing the effectiveness of an inverted classroom to a traditional classroom in an upperdivision engineering course. IEEE Transactions on Education, 56(4): 430-435. View at Google Scholar | View at Publisher

Merrill, M.D., 2002. First principles of instruction. Educational Technology Research and Development, 50(3): 43-59. View at Google Scholar |View at Publisher

O'Flaherty, J. and C. Pilips, 2015. The use of flipped classrooms in higher education: A scoping review. Internet and Higher Education, 25: 85-95. View at Google Scholar | View at Publisher

Ocak, G., 2004. The effect of videotape on reading comprehension level of 5th grade students in primary School. Primary-Online, 3(2): 19-25. View at Google Scholar

Orhan, F., 1999. Basic education in distance education approach I. Video teacher training in video assisted education. Hacettepe University Education Faculty Magazine, 16(17): 134-141. View at Google Scholar

Özcan, M. and Y. Balc1, 2016. Thoughts on academic research and publication. Business Ethics Magazine, 9(1): 91-116. View at Google Scholar View at Publisher

Pekdağ, B., 2010. Alternative ways in chemistry learning: Learning with animation, simulation, video and multimedia. Turkish Science Education Journal, 7(2): 79-1 10. View at Google Scholar

Roehl, A., S. Reddy and G. Shannon, 2013. The flipped classroom: An opportunity to engage millennial students through active learning strategies. Journal of Family and Consumer Sciences, 105(2): 44-49. View at Google Scholar | View at Publisher

Rogers, M.E., 2003. Diffusion of innovation. 5th Edn., New York: The Free Press.

Singh, H., 2003. Building effective blended learning programs. Educational Technology-Saddle Brook Then Englewood Cliffs NJ, 43(6): 5154. View at Google Scholar 
Sirakaya, D.A., 2015. The effect of the inverse classroom model on academic achievement, self-directed learning readiness and motivation. Ph.D. Thesis, Gazi University, Institute of Educational Sciences, Department of Computer and Instructional Technology Education, Ankara.

Staker, H. and M. Horn, 2012. Classifying K-12 blended learning. Retrieved from http://files.eric.ed.gov/fulltext/ED535180.pdf $[$ Accessed 02.04.2017].

Stifle, T.L., 2014. A case study transitioning a traditionally offered career counseling graduate course to a blended format: Analysis and recommendations. Doctoral Thesis, University of Redlands, Redlands, California, U.S.

Strayer, J.F., 2012. How learning in an inverted classroom influences cooperation, innovation and task orientation. Learning Environments Research, 15(2): 171-193. View at Google Scholar | View at Publisher

Sucu, F., M. Akbay and Y. Akbulut, 2015. Content management system in medical education: EDMODO. Journal of Medical Education and Informatics, 1(1): 24-32.

Talley, C.P. and S. Scherer, 2013. The enhanced flipped classroom: Increasing academic performance with student-recorded lectures and practice testing in a "flipped" stem course. Joumal of Negro Education, 82(3): 339-347. View at Google Scholar | View at Publisher

Torkelson, V., 2012. The flipped classroom, putting learning back into the hands of student. Master's Thesis, Saint Mary's College of California, California, U.S.

Turan, Z., 2015. Evaluation of inverse face class method and investigation of academic achievement, cognitive load and motivation. Doctorate Thesis, Atatürk University, Department of Computer and Instructional Technology Education, Erzurum.

Uçak, N.Ö. and H.G. Birinci, 2008. Scientific ethics and plagiarism. Turkish Librarianship, 22(2): 187-204. View at Google Scholar Ünsal, H., 2012. The impact of blended learning on success and motivation. Journal of Turkish Educational Sciences, 10(1): 27. View at Google
Scholar

Vaughan, M., 2014. Flipping the learning: An investigation into the use of the flipped classroom model in an introductory teaching course. Education Research and Perspectives, 41: 25-41. View at Google Scholar

Wilson, S.G., 2013. The flipped class: A method to address the challenges of an undergraduate statistics course. Teaching of Psychology, 4O(3): 193-199. View at Google Scholar

Yavuz, M., 2016. The impact of academic achievement of reverse classroom applications at secondary education level and examination of student experiences. Master Thesis. Erzurum: Atatürk University, Department of Educational Sciences, Department of Computer and Instructional Technology. 